\title{
Analisis Pengaruh Bauran Pemasaran dan Perilaku Konsumen terhadap Pengambilan Keputusan Pembelian Yoghurt di DKI Jakarta
}

\author{
Yunita Hasnah Devina ${ }^{1}$, Totok Pujianto ${ }^{2}$ dan Roni Kastaman ${ }^{3}$ \\ ${ }^{1}$ Program Studi Teknologi Industri Pertanian, Fakultas Teknologi Industri Pertanian, \\ Universitas Padjadjaran \\ ${ }^{2}$ Fakultas Teknologi Industri Pertanian, Universitas Padjadjaran \\ Jl. Raya Bandung-Sumedang KM 21 Jatinangor, Jawa Barat, 45363 \\ *Alamat korespondensi: totok.pujianto@unpad.ac.id
}

\begin{tabular}{|c|c|}
\hline INFO ARTIKEL & ABSTRACT/ABSTRAK \\
\hline Diterima: $\quad 16-03-2021$ & \\
\hline $\begin{array}{lr}\text { Direvisi: } \quad 17-06-2021 \\
\text { Dipublikasi: } 11-08-2021\end{array}$ & $\begin{array}{l}\text { Analysis of Marketing Mix and Consumer Behaviour Effect on Yoghurt } \\
\text { Purchasing Decision in DKI Jakarta }\end{array}$ \\
\hline
\end{tabular}

Keywords:

4P's, Consumer

behaviour,

Purchasing

decision

Kata Kunci:

4P, Keputusan

pembelian,

Perilaku konsumen
Yoghurt is a protein rich food resulting from milk fermentation that its consumption tends to increase in Indonesia. The existence of various types and brands of yoghurt in the Indonesian market is due to competition in gaining market share which is supported by this increasing number of consumers. The marketing mix is a set of marketing variables that can be controlled and used by the company to influence consumers in the market segment with the use of the right strategy. This study aimed to determine the influence of marketing mix and consumer behaviour factors on yoghurt purchase decision in DKI Jakarta. This study used descriptive method based on quantitative data. Data were collected by distributing questionnaires to 112 yoghurt consumers in DKI Jakarta through Google Forms and the data were analysed using descriptive analysis to describe the DKI Jakarta's yoghurt consumer characteristics and multiple linear regression analysis to determine the influence of some variables on yoghurt purchasing decisions in DKI Jakarta. The results showed that yoghurt consumer in DKI Jakarta dominated by undergraduate (75\%) woman students (48\%) who bought at supermarket (84\%). The results also showed that yoghurt purchases in DKI Jakarta dominantly influenced by the consumer behaviour rather than marketing mix factors (4P's) which had a significant influence on yoghurt purchasing decision in DKI Jakarta. The consumer behaviour factor consisted of cultural variable (1.194) and psychological variable (1.472) while the marketing mix factor consisted of the distribution variable (0.935).

Yoghurt merupakan produk fermentasi berbahan dasar susu kaya protein yang tingkat konsumsinya cenderung meningkat di Indonesia. Keberadaan berbagai jenis dan merek yoghurt di pasar Indonesia karena adanya persaingan dalam mendapatkan pangsa pasar yang didukung dengan peningkatan jumlah konsumen yang mengonsumsi yoghurt tersebut. Bauran pemasaran adalah serangkaian dari variabel pemasaran yang dapat dikuasai oleh perusahaan dan digunakan perusahaan untuk memengaruhi konsumen pada segmen pasar dengan penggunaan strategi yang tepat. Penelitian ini bertujuan untuk mengetahui pengaruh faktor bauran pemasaran dan perilaku konsumen terhadap keputusan pembelian produk yoghurt di DKI Jakarta. Penelitian menggunakan metode deskriptif 
berdasarkan data kuantatif. Data dikumpulkan dengan menyebarkan kuesioner kepada 112 konsumen yoghurt di DKI Jakarta melalui Google Formulir dan data dianalisis dengan analisis deskriptif untuk menggambarkan karakteristik umum konsumen yoghurt di DKI Jakarta dan analisis regresi liner berganda untuk mengetahui pengaruh variabel terhadap keputusan pembelian yoghurt di DKI Jakarta. Hasil penelitian menunjukkan bahwa konsumen pembelian yoghurt di DKI Jakarta didominasi oleh Mahasiswi (48\%) dengan latar pendidikan S1 (75\%) yang membeli di Swalayan (84\%). Hasil penelitian juga menunjukkan bahwa keputusan pembelian yoghurt di DKI Jakarta cenderung dominan dipengaruhi faktor perilaku konsumen dibandingkan dengan faktor bauran pemasaran produk (4P) yang memiliki pengaruh signifikan terhadap keputusan pembelian yoghurt di DKI Jakarta. Faktor perilaku konsumen terdiri dari variabel budaya $(1,194)$ dan psikologis $(1,472)$, serta faktor bauran pemasaran terdiri dari variabel distribusi $(0,935)$.

\section{PENDAHULUAN}

Pada saat ini, pola hidup sehat di kalangan masyarakat Indonesia semakin meningkat dan hal ini telah memengaruhi pola konsumsi masyarakat secara signifikan. Salah satu produk makanan yang dikonsumsi untuk meningkatkan kesehatan adalah yoghurt yang merupakan produk fermentasi berbahan dasar susu kaya kandungan protein hewani. Winarno (1992) menyebutkan bahwa kandungan protein pada yoghurt bahkan lebih tinggi daripada susu karena adanya penambahan protein dari sintesa mikroba pada proses pembuatan yoghurt. Proses pembuatan yoghurt adalah susu difermentasi menggunakan bakteri Lactobacillus bulgaricus dan Streptococcus termophilus menghasilkan cita rasa asam yang segar akibat turunnya $\mathrm{pH}$ dalam kondisi asam dan memiliki tekstrur yang kental (Widowati \& Misgiyarta, 2003).

Perkembangan yoghurt di Indonesia cenderung meningkat dengan ditandai adanya produksi dari berbagai jenis dan merek yoghurt di pasar Indonesia. Hal tersebut disebabkan karena adanya persaingan dalam mendapatkan pangsa pasar yang didukung dengan peningkatan jumlah konsumen yang mengonsumsi yoghurt. Penjualan produk memiliki persaingan antar penjualnya, maka perlu dilakukan peningkatan jumlah penjualan dengan memperhatikan bauran pemasaran. Pada dasarnya, perusahaan selalu dihadapkan pada beberapa faktor yang dapat dikendalikan oleh perusahaan dan tidak dapat dikendalikan oleh perusahaan. Keempat variabel bauran pemasaran dapat digunakan perusahaan untuk memengaruhi konsumen pada segmen pasar dengan penggunaan strategi yang tepat (Kasmir, 2016).

Keputusan pembelian produk yoghurt turut mempertimbangkan sikap konsumen terhadap atribut produk yoghurt. Sikap menjadi konsep terpenting dalam studi perilaku konsumen dikarenakan sikap adalah faktor psikologis yang perlu dipahami dan berkorelasi positif yang kuat terhadap nilai informasi keputusan pembelian produk yoghurt. Pemahaman karakteristik dan perilaku konsumen terhadap produk yoghurt diperlukan untuk mengetahui kebutuhan dan keinginan yang menggambarkan produk yoghurt yang dibutuhkan pasar. Kotler (2005) menyatakan bahwa faktor-faktor yang memengaruhi perilaku konsumen meliputi empat faktor utama yaitu faktor budaya, sosial, pribadi dan psikologi. Dengan demikian, pola konsumsi masyarakat terhadap suatu produk terbentuk karena pengaruh budaya, sosial, pribadi dan psikologi. Setelah mereka mengetahui produk yang dibutuhkan maka konsumen akan mengambil suatu keputusan apakah membeli atau tidak membeli produk tersebut (Suprayitno dkk., 2015).

Faktor bauran pemasaran dan perilaku konsumen dipertimbangkan dalam proses konsumen memutuskan suatu pembelian terhadap produk. Pada proses pemilihan keputusan dalam pembelian produk dilakukan dengan menggunakan salah satu dari beberapa alternatif produknya dilakukan dengan tindakan yang nyata yang kemudian pilihannya dievaluasi dan ditentukan sikap selanjutnya (Puspita dkk., 2015).

DKI Jakarta merupakan provinsi terpadat di Indonesia dengan jumlah penduduk 10.562.088 jiwa 
dengan kelompok usia muda (15-34 tahun) sebanyak 3.340.644 jiwa atau sekitar 33\% dari total penduduk DKI Jakarta (BPS DKI Jakarta, 2020). Selain itu, daya beli konsumen DKI Jakarta juga tinggi menjadi salah satu alasan pemasaran dan penjualan usaha itu baik dilakukan di DKI Jakarta. Namun, strategi dalam pemasaran produk atau dikenal dengan istilah $4 \mathrm{P}$ (Product, Price, Place, Promotion) diperlukan saat hendak melakukan pemasaran di Ibukota DKI Jakarta untuk dapat bersaing dengan usaha yang sudah berkembang lebih besar dibandingkan dengan usaha mikro kecil menengah atau usaha lokal.

Oleh karena upaya untuk menghadapi persaingan antar produsen yoghurt, penting bagi pelaku usaha yoghurt mempersiapkan strategi pemasaran produk di DKI Jakarta dengan mengetahui karakteristik konsumen yoghurt dan faktor yang memengaruhi proses pengambilan keputusan dalam pembelian produk yoghurt, seperti faktor produk, harga, distribusi, promosi, budaya, sosial, pribadi, dan psikologi. Guna mengetahui strategi yang tepat untuk diterapkan, maka perlu dilakukan analisis untuk mengetahui faktor yang memengaruhi keputusan pembelian yoghurt di DKI Jakarta dengan menggunakan analisis deskriptif untuk mengetahui karakteristik konsumen yoghurt di DKI Jakarta dan analisis regresi linear berganda untuk mengetahui besaran pengaruh pada faktor terkait pemasaran produk yoghurt di DKI Jakarta.

\section{BAHAN DAN METODE}

Penelitian dilakukan dari bulan Desember 2020 sampai bulan Februari 2021. Penelitian menggunakan jenis penelitian terapan metode deskriptif berdasarkan data kuantatif. Data dianalisis dengan menggunakan analisis deskriptif dan analisis regresi linear berganda. Penelitian menggunakan teknik Non-Probability Sampling dengan sampel tidak diberikan kesempatan yang sama bagi setiap anggota populasi untuk dijadikan sebagai sampel. Jenis pemilihan sampel yang digunakan adalan purposive sampling yang merupakan teknik penentuan sampel dengan beberapa pertimbangan atau syarat tertentu (Sugiyono, 2016). Objek penelitian dalam penelitian ini adalah konsumen yang berdomisili di DKI Jakarta dan pernah melakukan pembelian yoghurt dalam kemasan. Jumlah sampel yang digunakan untuk pengambilan data dihitung dengan menggunakan rumus di bawah ini. Rumus ini berdasarkan pada pertimbangan bahwa jumlah populasi relatif besar dan jumlahnya tidak dapat teridentifikasi dengan pasti yang menyebabkan kecil kemungkinan bahwa seluruh populasi dapat teramati atau diambil datanya (Wibisono, 2003; Riduwan, 2013) sebagai berikut:

$n=\frac{(z \alpha / 2 x \sigma)^{2}}{e}$

Keterangan:

$\mathrm{n}=$ Jumlah sampel

$\sigma=$ Standar deviasi $25 \%$ (ketetapan)

$\mathrm{e}=\operatorname{error}($ batas kesalahan $=5 \%)$

$z_{\alpha / 2}=$ Nilai dari tabel distribusi normal atas tingkat keyakinan $95 \%$

$z_{\alpha / 2}=1,96$

Berdasarkan rumus perhitungan jumlah sampel menurut Wibisono (2003), maka didapatkan:

$$
\begin{aligned}
& n=\frac{(1,96 \times 0,25)^{2}}{0,05} \\
& n=96,04 \approx 100 \text { sampel }
\end{aligned}
$$

Pada saat pengumpulan data kuesioner diisi oleh 112 responden, dimana sudah melampaui target sampel responden sebanyak 100 sampel. Oleh karena itu, penelitian diolah menggunakan 112 jawaban responden. Metode pengumpulan data diawali dengan identifikasi variabel yang termasuk aktor bauran pemasaran dan perilaku konsumen dirancang menjadi kuesioner penelitian dengan penggunaan skala likert berskala 4 sesuai dengan tingkat persetujuan responden terhadap pernyataan pada kuesioner yang diberikan. Skala likert terdiri dari 1: sangat tidak setuju, 2: kurang setuju, 3 : setuju, dan 4: sangat setuju. Rancangan kuesioner diuji dengan menyebarkan kuesioner ke sejumlah responden, kemudian diuji validitas dan reabilitas. Dasar pengembangan pembuatan kuesioner mengenai karakteristik konsumen, bauran pemasaran, dan perilaku konsumen disajikan pada Tabel 1 dan Tabel 2. 
Tabel 1. Operasional variabel penelitian karakteristik konsumen

\begin{tabular}{|c|c|c|}
\hline Variabel & Definisi operasional & Indikator/ukuran/parameter \\
\hline Usia & $\begin{array}{l}\text { Lama tahun yang dilalui } \\
\text { responden berdasarkan tahun } \\
\text { kelahirannya }\end{array}$ & $\begin{array}{l}\text { 1. } \\
\text { 2. } \\
\text { 3. } \\
\text { 3. } 36-55 \text { tahun tahun } \\
\text { 4. } \quad>55 \text { tahun }\end{array}$ \\
\hline Jenis kelamin & Identitias gender individu & $\begin{array}{ll}\text { 1. } & \text { Laki-laki } \\
\text { 2. } & \text { Perempuan }\end{array}$ \\
\hline Pendidikan & $\begin{array}{l}\text { Tingkat pendidikan formal } \\
\text { responden }\end{array}$ & $\begin{array}{ll}\text { 1. } & \text { SMA } \\
\text { 2. } & \text { D3 } \\
\text { 3. } & \text { S1 } \\
\text { 4. } & \text { S2 }\end{array}$ \\
\hline Pekerjaan & $\begin{array}{l}\text { Jenis kegiatan bekerja yang } \\
\text { dilakukan oleh individu }\end{array}$ & $\begin{array}{ll}\text { 1. } & \text { Pelajar/mahasiswa } \\
\text { 2. } & \text { Wirausaha } \\
\text { 3. } & \text { Wiraswasta } \\
\text { 4. } & \text { PNS } \\
\text { 5. Ibu rumah tangga } \\
\text { 6. } & \text { Lainnya }\end{array}$ \\
\hline Pendapatan & $\begin{array}{l}\text { Jumlah penghasilan dalam satu } \\
\text { bulan untuk memenuhi } \\
\text { kebutuhan diri }\end{array}$ & $\begin{array}{ll}1 . & <\text { Rp. } 2.000 .000 \\
\text { 2. } & \text { Rp.2.000.000-Rp.4.999.000 } \\
\text { 3. } & \text { Rp.5.000.000-Rp.7.999.000 } \\
\text { 4. } & >\text { Rp. } 8.000 .000\end{array}$ \\
\hline $\begin{array}{l}\text { Kuantitas konsumsi } \\
\text { yoghurt per minggu }\end{array}$ & $\begin{array}{l}\text { Jumlah yoghurt yang diminum } \\
\text { oleh konsumen selama satu } \\
\text { minggu }\end{array}$ & $\begin{array}{ll}1 . & <100 \mathrm{ml} \\
\text { 2. } & 100-250 \mathrm{ml} \\
\text { 3. } & 250-500 \mathrm{ml} \\
\text { 4. } & 500-1000 \mathrm{ml}\end{array}$ \\
\hline $\begin{array}{l}\text { Anggaran dana membeli } \\
\text { yoghurt }\end{array}$ & $\begin{array}{l}\text { Sejumlah dana yang diperuntukan } \\
\text { pembelian yoghurt dalam satu } \\
\text { bulan }\end{array}$ & $\begin{array}{ll}1 . & <\text { Rp. } 50.000 \\
\text { 2. } & \text { Rp. } 50.000-\text { Rp. } 99.000 \\
\text { 3. } & \text { Rp. } 100.000-\text { Rp. } 199.000 \\
\text { 4. } & >\text { Rp. } 200.000\end{array}$ \\
\hline Informasi produk & $\begin{array}{l}\text { Sumber informasi mengenai } \\
\text { produk yang dijumpai konsumen }\end{array}$ & $\begin{array}{ll}\text { 1. } & \text { Iklan } \\
\text { 2. } & \text { Teman } \\
\text { 3. } & \text { Keluarga } \\
\text { 4. } & \text { Rekan Kerja } \\
\text { 5. } & \text { Lainnya } \\
\end{array}$ \\
\hline Tempat pembelian & $\begin{array}{l}\text { Tempat konsumen melakukan } \\
\text { pembelian yoghurt kemasan }\end{array}$ & $\begin{array}{l}\text { 1. Toko khusus yoghurt } \\
\text { 2. Swalayan } \\
\text { 3. Online store }\end{array}$ \\
\hline
\end{tabular}

Pengujian instrumen kuesioner dilakukan untuk mengetahui instrumen yang digunakan berkualitas dan layak dijadikan sebagai alat ukur. Uji validitas menggunakan korelasi product moment dengan ketentuan, jika rhitung $>$ rabel maka pertanyaan dinyatakan valid. Hasil pengujian validitas menyatakan bahwa pertanyaan pada kuesioner sudah valid dengan rhitung $>0,312$ (rrabel; 40 responden; tingkat kepercayan $95 \%=0,312$ ) pada keseluruhan pertanyaan.

Uji reliabilitas dilakukan untuk mengetahui bahwa kuesioner dapat menjadi alat pengukuran yang dapat diandalkan dengan hasil yang konsisten. Pengujian reliabilitas menggunakan Alpha Cronbach dengan nilai Cronbach's Alpha pada variabel $\mathrm{X}$ dan variabel $Y$ sebesar $\alpha>0,8$, sehingga dapat disimpulkan bahwa pertanyaan pada instrumen penelitian memiliki reliabilitas tinggi yang memiliki arti bahwa instrumen sebagai alat ukur kuat dan secara keseluruhan hasil instrumen dinyatakan konsisten. 
Tabel 2. Operasional variabel penelitian bauran pemasaran dan perilaku konsumen

\begin{tabular}{|c|c|c|c|}
\hline \multicolumn{2}{|c|}{ Variabel } & Definisi Operasional & \multirow[t]{2}{*}{ Indikator } \\
\hline \multicolumn{3}{|r|}{ Variabel Bebas (X) } & \\
\hline \multirow{14}{*}{$\begin{array}{l}\text { Bauran } \\
\text { pemasaran }\end{array}$} & Product & Sesuatu yang ditawarkan di pasar & 1. Ragam/variasi \\
\hline & & untuk diperlihatkan, dimiliki, dan & 2. Kemasan \\
\hline & & digunakan untuk memenuhi & 3. Merek \\
\hline & & kebutuhan & 4. Manfaat \\
\hline & Pricel & Persepsi konsumen terhadap nilai & 1. Harga sebanding dengan produk \\
\hline & Harga & dari produk yoghurt & 2. Keterjangkauan harga \\
\hline & & & 3. Harga bersaing dengan competitor \\
\hline & & & 4. Metode pembayaran \\
\hline & Placel & Pengelolaan saluran perdagangan & 1. Ketersediaan produk \\
\hline & Distribusi & untuk menyalurkan produk & 2. Kemudahan mendapatkan produk \\
\hline & Promotion/ & Langkah publikasi & 1. Iklan \\
\hline & Promosi & mengkomunikasikan maanfaat & 2. Diskon \\
\hline & & produk dan membujuk target & 3. Relasi dengan publik \\
\hline & & $\begin{array}{l}\text { konsumen untuk melakukan } \\
\text { pembelian }\end{array}$ & \\
\hline \multirow[t]{9}{*}{$\begin{array}{l}\text { Perilaku } \\
\text { konsumen }\end{array}$} & Budaya & $\begin{array}{l}\text { Penentu keinginan dan perilaku } \\
\text { mendasar pembeli }\end{array}$ & 1. Budaya \\
\hline & Sosial & Sekelompok orang yang memiliki & 1. Teman/ keluarga \\
\hline & & $\begin{array}{l}\text { pengaruh secara langsung terhadap } \\
\text { sikap seseorang }\end{array}$ & 2. Media massa \\
\hline & Pribadi & Faktor pribadi yang mempengaruhi & 1. Usia \\
\hline & & gaya hidup seseorang & 2. Pekerjaan \\
\hline & & & 3. Ekonomi \\
\hline & & & 4. Gaya hidup \\
\hline & Psikologis & Perilaku dan aktivitas induvidu & 1. Persepsi \\
\hline & & secara emosional & 2. Pengatahuan/keyakinan \\
\hline \multicolumn{4}{|c|}{ Variabel Terikat $(\mathrm{Y})$} \\
\hline \multirow{7}{*}{$\begin{array}{l}\text { Keputusan } \\
\text { pembelian } \\
\text { konsumen }\end{array}$} & $\begin{array}{l}\text { Pengenalan } \\
\text { kebutuhan }\end{array}$ & $\begin{array}{l}\text { Dorongan kebutuhan manfaat dan } \\
\text { pentingnya mengonsumsi yoghurt }\end{array}$ & 1. Motivasi pembelian \\
\hline & Pencarian & Pencarian pengetahuan mengenai & 1. Sumber informasi utama pembeli \\
\hline & informasi & yoghurt & $\begin{array}{l}\text { 2. Aspek informasi yang menarik } \\
\text { perhatian pembeli }\end{array}$ \\
\hline & $\begin{array}{l}\text { Evaluasi } \\
\text { alternatif }\end{array}$ & $\begin{array}{l}\text { Tindakan responden menilai dan } \\
\text { membandingkan informasi terhadap } \\
\text { atribut pada yoghurt }\end{array}$ & $\begin{array}{l}\text { 1. Kriteria pertimbangan pembeli saat } \\
\text { melakukan pembelian }\end{array}$ \\
\hline & $\begin{array}{l}\text { Keputusan } \\
\text { pembelian }\end{array}$ & $\begin{array}{l}\text { Memutuskan melakukan pembelian } \\
\text { yoghurt }\end{array}$ & $\begin{array}{l}\text { 1. Waktu pembelian yoghurt } \\
\text { 2. Proses pembeli }\end{array}$ \\
\hline & Perilaku & Penilaian konsumen terhadap & 1. Tingkat kepuasan \\
\hline & $\begin{array}{l}\text { pasca } \\
\text { pembelian }\end{array}$ & produk yoghurt yang telah dibeli & $\begin{array}{l}\text { 2. Pembelian kembali } \\
\text { yoghurt }\end{array}$ \\
\hline
\end{tabular}

Pengujian instrumen kuesioner dilakukan untuk mengetahui instrumen yang digunakan berkualitas dan layak dijadikan sebagai alat ukur. Uji validitas menggunakan korelasi product moment dengan ketentuan, jika rhitung $>$ rtabel maka pertanyaan dinyatakan valid. Hasil pengujian validitas menyatakan bahwa pertanyaan pada kuesioner sudah valid dengan rhitung $>0,312$ ( $\mathrm{r}_{\text {rabel }} ; 40$ responden; tingkat kepercayaan $95 \%=0,312$ ) pada keseluruhan pertanyaan. Uji reliabilitas dilakukan untuk mengetahui bahwa kuesioner dapat menjadi alat pengukuran yang dapat diandalkan dengan hasil yang konsisten. Pengujian reliabilitas menggunakan Alpha Cronbach dengan nilai Cronbach's Alpha pada variabel X dan variabel 
Y sebesar $\alpha>0,8$, sehingga dapat disimpulkan bahwa pertanyaan pada instrumen penelitian memiliki reliabilitas tinggi yang memiliki arti bahwa instrumen sebagai alat ukur kuat dan secara keseluruhan hasil instrumen dinyatakan konsisten.

Setelah dinyatakan valid dan reliabel, kuesioner dapat disebarkan kepada responden secara daring (dalam jaringan/online) melalui layanan bantuan Google berupa Google Formulir. Saat data telah terkumpul, data yang diolah perlu dilakukan pengujian prasyarat sebelum dianalisis dengan menggunakan analisis deskriptif dan analisis regresi linear berganda agar hasil dapat dipastikan akurat dan tidak bias. Pengujian awal dilakukan untuk memastikan bahwa data terbebas dari gejala heteroskedastisitas, terbebas dari gejala multikolineritas, dan data bersifat normal sehingga menghasilkan hasil yang akurat mengenai hasil analisisnya. Berdasarkan hasil pengujian normalitas metode Saphiro Wilk dinyatakan bahwa data terdistribusi normal dengan nilai signifikasi 0,2, tidak menunjukkan adanya gejala multikolinearitas karena nilai VIF (Variance Inflation Factor) dari 8 variabel kurang dari 10 dan nilai tolerance pada 8 variabel lebih dari 0,1 , dan tidak menunjukkan adanya gejala heteroskedastisitas dikarenakan melalui uji Rank Spearman memiliki nilai signifikansi lebih dari 0,05 . Setelah data dipastikan memenuhi prasyarat uji analisis regresi, maka data dianalisis dengan analisis deskrispsi untuk mengetahui persentase yang mendominasi dan analisis regresi linear yang menghasilkan persamaan regresi untuk mengetahui besaran pengaruh variabel secara parsial dan simultan.

\section{HASIL DAN PEMBAHASAN}

\section{Karakteristik Konsumen}

Karakterisasi responden bertujuan untuk memberikan gambaran dari uraian identitas responden sampel penelitian terhadap penelitian. Pembelian yoghurt kemasan dan suka mengonsumsi yoghurt secara umum di wilayah DKI Jakarta didominasi oleh perempuan (74\%) (Gambar 1a). Jenis kelamin dapat menentukan orientasi sikap dan perilaku seseorang yang dipengaruhi faktor genetik. Menurut Logen (2015), perempuan memiliki tingkat kekhawatiran dan memiliki perhatian yang lebih terhadap kondisi kesehatannya dibanding dengan laki-laki, dimana dengan mengonsumsi yoghurt dapat menerima beberapa manfaat kesehatan bagi tubuh seperti memberikan nutrisi bagi kulit, mencegah infeksi vagina, serta mengatasi berbagai jenis gangguan pencernaan. Sebaran usia dewasa awal di DKI Jakarta (63\%) mendominasi sebagai pelaku dalam pembelian yoghurt kemasan (Gambar 1b). Pada usia dewasa cenderung berpikir jangka panjang, termasuk kesehatan untuk masa mendatang, dibandingkan dengan usia remaja terutama dalam memenuhi keseimbangan makanan bergizi di dalam padatnya aktivitas kehidupan sehari-hari (Suprayitno dkk., 2015).
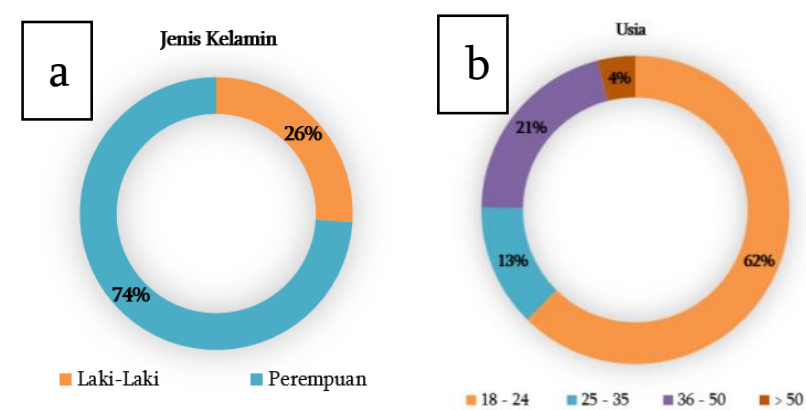

Gambar 1. Karakteristik konsumen responden penelitian. (a) Berdasarkan jenis kelamin. (b) Berdasarkan usia.

Tingkatan pendidikan konsumen yoghurt kemasan di DKI Jakarta didominasi oleh sarjana (75\%) (Gambar 2a). Pendidikan yang ditempuh oleh seseorang dapat memengaruhi pola pikir seseorang, menentukan kapasitas seseorang dalam menerima informasi pengetahuan, memengaruhi proses pengolahan informasi, dan dapat memengaruhi perilaku seseorang dalam melakukan keputusan pembelian terhadap suatu produk (Sumarwan, 2011). Jenis pekerjaan responden konsumen yoghurt kemasan di DKI Jakarta didominsi oleh pelajar atau mahasiswa (48\%) (Gambar 2b). Jenis pekerjaan yang berbeda memiliki beban kerja yang berbeda, sehingga perlu diperhatikan agar kinerja kerja stabil 
dan berjalan baik. Salah satu upaya yang dapat dilakukan dengan mengonsumsi yoghurt guna menjaga keseimbangan gizi dan kesehatan tubuh sehingga beban pekerjaan dapat diselesaikan dengan baik (Gayatri, 2015).
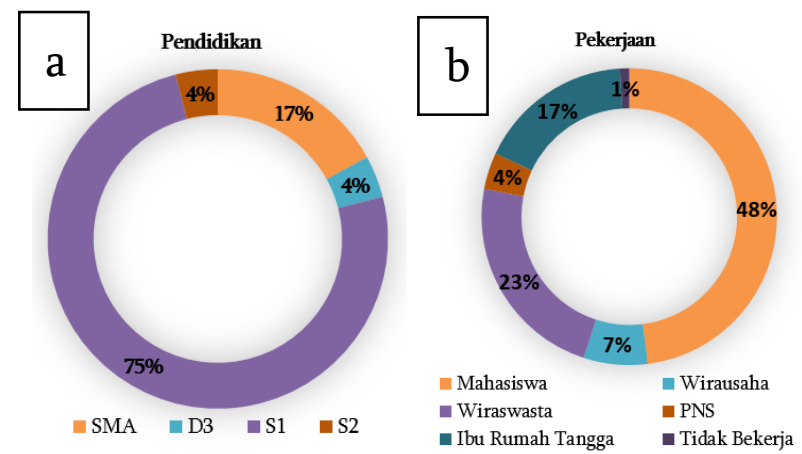

Gambar 2. Karakteristik konsumen responden penelitian. (a) Berdasarkan tingkat pendidikan. (b) Berdasarkan jenis pekerjaan.

Jumlah pendapatan yang dimiliki oleh responden konsumen yoghurt kemasan di DKI Jakarta didominsi pendapatan yang nilainya lebih kecil dari Rp.2.000.000 (Gambar 3a) yang merupakan pendapatan dengan golongan terkecil sehingga dapat dikatakan konsumen yoghurt kemasan berasal dari berbagai macam jenis kalangan. Pendapatan dapat juga memengaruhi pola konsumsi seseorang dalam pemuasan kebutuhan seseorang yang kemudian dapat memengaruhi daya beli seseorang terhadap suatu produk (Priambodo \&
Najib, 2014). Responden konsumen yoghurt di wilayah DKI Jakarta memiliki rata-rata jumlah kuantitas konsumsi yoghurt dalam jangka satu minggu sebanyak 0 - $250 \mathrm{ml}$ (46\%) (Gambar 3b). Jumlah kuantitas volume yoghurt yang disarankan untuk dikonsumsi dalam sehari sebanyak $680 \mathrm{~g} / \mathrm{hari}$ dengan tujuan menjaga keseimbangan jumlah bakteri baik yang berada di usus sehingga dapat membantu dalam proses penyerapan nutrisi dari makanan dengan baik (Setiaputri \& Firdaus, 2020).
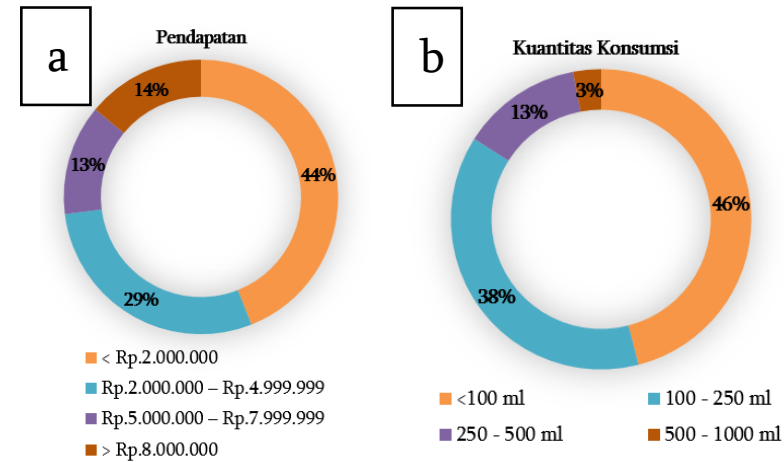

Gambar 3. Karakteristik konsumen responden penelitian. (a) Berdasarkan pendapatan konsumen. (b) Berdasarkan kuantitas yoghurt per minggu.

Dinyatakan bahwa responden belum menjadikan produk yoghurt sebagai produk yang diprioritaskan dikarenakan anggaran untuk pembelian yoghurt dalam sebulan hanya sebesar kurang dari Rp.50.000 (76\%) (Gambar 4a). Konsumen menjadikan yoghurt sebagai makanan pelengkap makanan pokok sehingga yoghurt bersifat hanya sebagai pelengkap (Yulia, 2015). Sumber informasi yang mendapat perhatian lebih oleh konsumen berasal dari iklan (51\%) (Gambar 4b) yang dipasangkan oleh produk yoghurt di beberapa media dan berbagai tempat. Sesuai dengan teori efek komunikasi massa bahwa informasi yang disampaikan melalui iklan dijadikan sebagai pengetahuan mengenai produk, adanya informasi turut meningkatkan dukungan moral terhadap minat beli produk, dan informasi memberikan persepsi terhadap produk (Asni, 2018). 

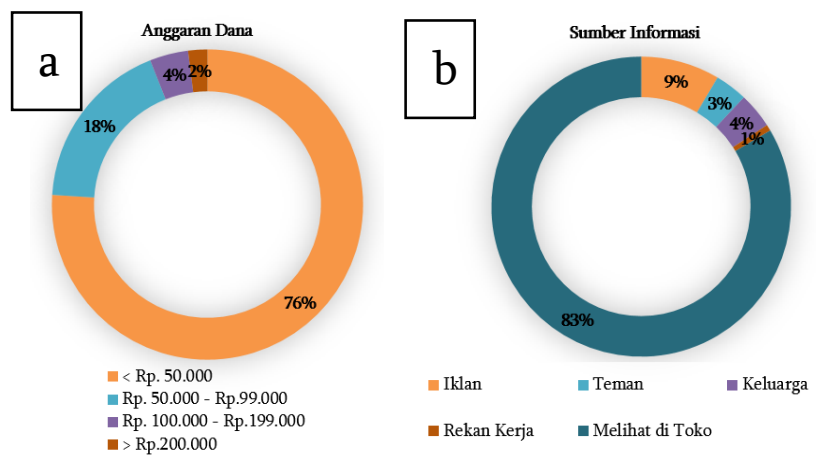

Gambar 4. Karakteristik konsumen responden penelitian. (a) Berdasarkan anggaran dana untuk yoghurt per bulan. (b) Berdasarkan sumber informasi produk.

Swalayan (84\%) menjadi tempat secara umum konsumen yoghurt DKI Jakarta, khususnya responden, melakukan pembelian yoghurt (Gambar 5). Latar belakang konsumen melakukan pembelian yoghurt di swalayan didasari dengan kelengkapan produk yang terdapat pada swalayan, kualitas pelayanan, dan fasilitas yang memudahkan konsumen untuk melakukan proses pembelian (Yedida dkk., 2016).

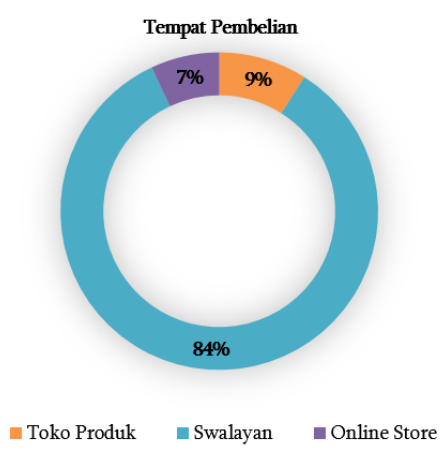

Gambar 5. Karakteristik konsumen berdasarkan tempat pembelian yoghurt.

\section{Analisis Deskriptif}

Data pada Tabel 3 merupakan deskripsi variabel untuk menginterpretasikan nilai kecenderungan dari masing-masing variabel pada hasil responden. Berdasarkan tanggapan responden pada Tabel 3 konsumen saat melakukan pembelian yoghurt memperhitungkan aspek ketersediaan variasi (warna, ukuran, dan rasa), kemasan yang menarik, aman, dan mudah dibawa, dan tentu manfaat produk menjadi nilai utama yang diperhitungkan dalam pembelian suatu produk. Selain itu, pemberian merek yang mudah dan menarik pada suatu produk turut memberikan nilai pengaruh terhadap keputusan pembelian produk. Harga yang memberikan pengaruh besar terhadap keputusan pembelian adalah harga saing yang terjangkau dan sesuai dengan kualitas produk. Konsumen juga cenderung membeli produk yang mudah diperoleh atau selalu tersedia di pasar. Promosi yang dijumpai oleh responden melalui iklan, media sosial, pemberian diskon, dan bazaar.

Secara budaya, mayoritas responden mengonsumsi yoghurt dengan tujuan kesehatan dan sebagian responden ada juga yang mengonsumsi karena gaya hidup modern. Keputusan pembelian seseorang dapat dipengaruhi saran dari orang lain, tetapi saran dari influencer yang berasa di media sosial tidak mendapatkan kepercayaan dari responden. Secara pribadi, hal-hal yang berasal dari diri sendiri seperti usia, pendapatan, dan kebutuhan diperhitungkan dalam keputusan pembelian yoghurt sesuai dengan kebutuhan diri masing-masing. Secara psikologis, keputusan pembelian yoghurt dilalui dengan proses meyakini bahwa yoghurt dapat meningkatkan kualitas hidup karena memiliki bakteri yang baik bagi tubuh. 
Tabel 3. Tanggapan responden

\begin{tabular}{|c|c|c|c|c|c|c|c|}
\hline & No. & Kode & Tanggapan responden & STS & TS & $\mathrm{S}$ & SS \\
\hline \multirow{32}{*}{ 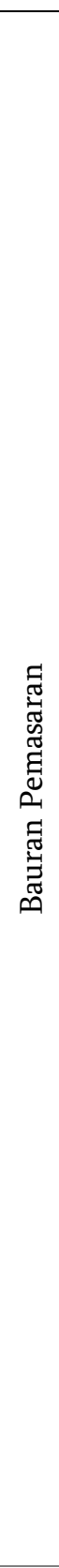 } & \multicolumn{7}{|c|}{ Variabel Produk } \\
\hline & 1 & A1 & $\begin{array}{l}\text { Ketersediaan variasi pada warna, ukuran, rasa } \\
\text { yoghurt }\end{array}$ & $\begin{array}{c}2 \\
2 \%\end{array}$ & $\begin{array}{c}7 \\
6 \%\end{array}$ & $\begin{array}{c}41 \\
37 \%\end{array}$ & $\begin{array}{c}62 \\
55 \%\end{array}$ \\
\hline & \multirow[t]{2}{*}{2} & A2 & Kemasan produk yang menarik & 1 & 15 & 59 & 37 \\
\hline & & & & $1 \%$ & $13 \%$ & $53 \%$ & $33 \%$ \\
\hline & \multirow[t]{2}{*}{3} & A3 & Kemasan produk yang mudah dibawa & 1 & 10 & 53 & 48 \\
\hline & & & & $1 \%$ & $9 \%$ & $47 \%$ & $43 \%$ \\
\hline & \multirow[t]{2}{*}{4} & A4 & Penamaan merek produk yoghurt yang menarik & 2 & 23 & 56 & 31 \\
\hline & & & dan mudah diingat & $2 \%$ & $21 \%$ & $50 \%$ & $28 \%$ \\
\hline & \multirow[t]{2}{*}{5} & A5 & Produk memiliki manfaat bagi kesehatan & 0 & 4 & 37 & 71 \\
\hline & & & & $0 \%$ & $4 \%$ & $33 \%$ & $63 \%$ \\
\hline & \multicolumn{7}{|c|}{ Variabel Harga } \\
\hline & 1 & A6 & Harga produk sesuai dengan kualitas yang & $\begin{array}{c}0 \\
0 \%\end{array}$ & $\begin{array}{c}3 \\
3 \%\end{array}$ & $\begin{array}{c}49 \\
44 \%\end{array}$ & $\begin{array}{c}60 \\
54 \%\end{array}$ \\
\hline & \multirow{2}{*}{2} & A7 & Harga produk yang ditawarkan terjangkau & 2 & $3 \%$ & 49 & 58 \\
\hline & & & & $2 \%$ & $3 \%$ & $44 \%$ & $52 \%$ \\
\hline & \multirow[t]{2}{*}{3} & A8 & Penawaran harga produk yoghurt antar merek & 3 & 14 & 51 & 45 \\
\hline & & & & $3 \%$ & $13 \%$ & $46 \%$ & $40 \%$ \\
\hline & \multirow[t]{2}{*}{4} & A9 & Variasi metode pembayaran untuk kemudahan & 6 & 31 & 51 & 25 \\
\hline & & & transaksi & $5 \%$ & $28 \%$ & $46 \%$ & $22 \%$ \\
\hline & \multicolumn{7}{|c|}{ Variabel Distribusi } \\
\hline & \multirow[t]{2}{*}{1} & A10 & Kemudahan memperoleh produk yoghurt & 0 & 4 & 46 & 62 \\
\hline & & & yang selalu tersedia di pasar & $0 \%$ & $4 \%$ & $41 \%$ & $55 \%$ \\
\hline & \multirow[t]{2}{*}{2} & A11 & Ketersediaan informasi produk yang lengkap & 1 & 10 & 53 & 48 \\
\hline & & & dan mudah didapatkan & $1 \%$ & $9 \%$ & $47 \%$ & $43 \%$ \\
\hline & \multicolumn{7}{|c|}{ Variabel Promosi } \\
\hline & \multirow[t]{2}{*}{1} & A12 & Promosi melalui iklan yang menarik perhatian & 3 & 23 & 49 & 37 \\
\hline & & & pada saat di jalan & $3 \%$ & $21 \%$ & $44 \%$ & $33 \%$ \\
\hline & \multirow[t]{2}{*}{2} & A13 & Promosi memanfaatkan sosial media secara & 4 & 17 & 43 & 49 \\
\hline & & & kreatif & $3 \%$ & $15 \%$ & $38 \%$ & $44 \%$ \\
\hline & \multirow[t]{2}{*}{3} & A14 & Promosi dengan menghadirkan potongan harga & 1 & 8 & 36 & 67 \\
\hline & & & & $1 \%$ & $7 \%$ & $32 \%$ & $60 \%$ \\
\hline & \multirow[t]{2}{*}{4} & A15 & Penjualan produk yoghurt pada event/ bazaar/ & 1 & 19 & 53 & 39 \\
\hline & & & $\begin{array}{l}\text { stand yang menciptakan hubungan baik dengan } \\
\text { masyarakat }\end{array}$ & $1 \%$ & $17 \%$ & $47 \%$ & $35 \%$ \\
\hline \multirow{13}{*}{ 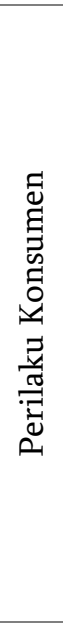 } & \multicolumn{7}{|c|}{ Variabel Budaya } \\
\hline & 1 & A16 & Mengonsumsi dengan tujuan untuk kesehatan & 1 & 9 & 47 & 55 \\
\hline & & & & $1 \%$ & $8 \%$ & $42 \%$ & $49 \%$ \\
\hline & 2 & A17 & Mengonsumsi karena gaya hidup modern yang & 15 & 41 & 41 & 15 \\
\hline & & & serba praktis & $13 \%$ & $37 \%$ & $37 \%$ & $13 \%$ \\
\hline & & & $\begin{array}{ll}\text { Variabel Sosial } \\
\end{array}$ & & & & \\
\hline & 1 & A18 & Saran dari orang terdekat/ teman menjadi acuan & 12 & 31 & 47 & 22 \\
\hline & & & dalam pembelian produk & $11 \%$ & $28 \%$ & $42 \%$ & $20 \%$ \\
\hline & 2 & A19 & Saran dari influencer di media sosial menjadi & 18 & 50 & 31 & 13 \\
\hline & & & acuan tambahan dalam pembelian produk & $16 \%$ & $45 \%$ & $28 \%$ & $12 \%$ \\
\hline & & & Variabel Pribadi & & & & \\
\hline & 1 & A20 & Usia mempengaruhi pola pikir untuk & 7 & 31 & 55 & 19 \\
\hline & & & mengonsumsi suatu produk dalam kehidupan & $6 \%$ & $28 \%$ & $49 \%$ & $17 \%$ \\
\hline
\end{tabular}




\begin{tabular}{|c|c|c|c|c|c|c|c|}
\hline & No. & Kode & Tanggapan responden & STS & TS & S & SS \\
\hline & & & sehari-hari & & & & \\
\hline & 2 & A21 & Menjaga kesehatan tubuh karena kesibukan & 2 & 20 & 64 & 26 \\
\hline & & & (beban kerja) & $2 \%$ & $18 \%$ & $57 \%$ & $23 \%$ \\
\hline & 3 & A22 & Mengonsumsi suatu produk sesuai dengan & 4 & 21 & 52 & 35 \\
\hline & & & pendapatan yang dimiliki & $4 \%$ & $19 \%$ & $46 \%$ & $31 \%$ \\
\hline & 4 & A23 & Mengonsumsi untuk menghemat waktu untuk & 6 & 34 & 47 & 25 \\
\hline & & & memenuhi gizi bagi tubuh & $5 \%$ & $30 \%$ & $42 \%$ & $22 \%$ \\
\hline & & & $\begin{array}{ll}\text { Variabel Psikologis } \\
\end{array}$ & & & & \\
\hline & 1 & A24 & Mengonsumsi yoghurt untuk meningkatkan & 3 & 13 & 64 & 33 \\
\hline & & & kualitas hidup dengan gaya hidup sehat & $2 \%$ & $12 \%$ & $57 \%$ & $29 \%$ \\
\hline & 2 & A25 & Produk memiliki bakteri baik untuk tubuh & 0 & 3 & 59 & 50 \\
\hline & & & & $0 \%$ & $3 \%$ & $53 \%$ & $45 \%$ \\
\hline \multirow{29}{*}{ 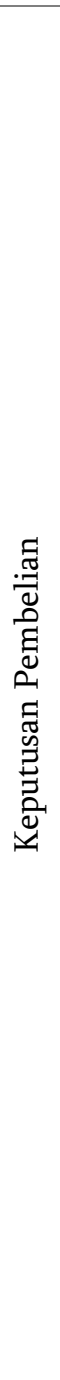 } & \multicolumn{7}{|c|}{ Pengenalan Kebutuhan } \\
\hline & \multirow[t]{2}{*}{1} & B1 & Mendapatkan manfaat bagi kesehatan tubuh & 0 & 5 & 53 & 54 \\
\hline & & & & $0 \%$ & $4 \%$ & $47 \%$ & $48 \%$ \\
\hline & \multirow[t]{2}{*}{2} & $\mathrm{~B} 2$ & Produk praktis dikonsumsi dimana dan kapan & 0 & 11 & 53 & 48 \\
\hline & & & saja & $0 \%$ & $10 \%$ & $47 \%$ & $43 \%$ \\
\hline & \multicolumn{7}{|c|}{ Pencarian Informasi } \\
\hline & \multirow[t]{2}{*}{1} & B3 & Saya mengetahui informasi mengenai produk & 7 & 20 & 57 & 28 \\
\hline & & & yoghurt melalui iklan (offline/ online) & $7 \%$ & $18 \%$ & $51 \%$ & $25 \%$ \\
\hline & \multirow[t]{2}{*}{2} & B4 & Kemudahan mendapatkan informasi mengenai & 2 & 13 & 64 & 33 \\
\hline & & & produk & $2 \%$ & $12 \%$ & $57 \%$ & $29 \%$ \\
\hline & \multicolumn{7}{|c|}{ Evaluasi Alternatif } \\
\hline & \multirow[t]{2}{*}{1} & B5 & Kualitas produk (rasa, bahan komposisi, bahan & 1 & 3 & 39 & 69 \\
\hline & & & pendukung, desain kemasan) & $1 \%$ & $3 \%$ & $35 \%$ & $62 \%$ \\
\hline & \multirow[t]{2}{*}{2} & B6 & Keterjangakauan harga produk dengan kualitas & 4 & 5 & 45 & 58 \\
\hline & & & produk & $4 \%$ & $4 \%$ & $40 \%$ & $52 \%$ \\
\hline & \multirow[t]{2}{*}{3} & B7 & Kemudahan mendapatkan produk dan & 0 & 4 & 44 & 64 \\
\hline & & & ketersediaan produk setiap saat & $0 \%$ & $4 \%$ & $39 \%$ & $57 \%$ \\
\hline & & & Keputusan Pembelian & & & & \\
\hline & 1 & B8 & Saya melakukan pembelian produk ketika & 0 & 10 & 56 & 46 \\
\hline & & & membutuhkan manfaat dari produk & $0 \%$ & $9 \%$ & $50 \%$ & $41 \%$ \\
\hline & 2 & B9 & Saya melakukan pembelian produk karena & 0 & 3 & 43 & 66 \\
\hline & & & menyukai pada variasi rasa dan kualitas produk & $0 \%$ & $3 \%$ & $38 \%$ & $59 \%$ \\
\hline & & & Perilaku Pasca Pembelian & & & & \\
\hline & 1 & B10 & Saya merasa puas setelah mengonsumsi yoghurt & 1 & 5 & 61 & 45 \\
\hline & & & & $1 \%$ & $4 \%$ & $54 \%$ & $40 \%$ \\
\hline & 2 & B11 & Saya akan melakukan pembelian produk & 1 & 3 & 58 & 50 \\
\hline & & & kembali & $1 \%$ & $3 \%$ & $52 \%$ & $45 \%$ \\
\hline & 3 & B12 & Saya akan merekomendasikan produk yoghurt & 1 & 14 & 65 & 32 \\
\hline & & & & $1 \%$ & $13 \%$ & $58 \%$ & $29 \%$ \\
\hline
\end{tabular}

Keterangan: STS = Sangat Tidak Setuju, TS = Tidak Setuju, $\mathrm{S}=$ Setuju, SS = Sangat Setuju.

Faktor keputusan pembelian terdiri dari beberapa tahapan hingga seseorang melakukan pembelian produk. Diawali dengan tahapan pengenalan kebutuhan konsumen dengan menyesuaikan manfaat produk dengan kebutuhan.
Kemudian konsumen mencari informasi mengenai produk melalui media offline/online sehingga kemudahan konsumen saat mendapatkan informasi memberikan nilai pengaruh kepada keputusan pembelian konsumen. Kemudian konsumen 
mengevalusi pilihan produk secara kualitas produk, keterjangkauan harga, dan kemudahan mendapatkan produk. Tahapan selanjutnya konsumen memutuskan untuk membeli produk, pada tahapan ini diperhatikan kenyamanan konsumen bertransaksi. Tahap terakhir adalah rasa yang dirasakan konsumen setelah menggunakan produk dan jika konsumen merasa puas, maka konsumen dapat melakukan pembelian produk kembali dan merekomendasikan produk dengan kerabat yang menguntungkan bagi produk yang dijual.

\section{Analisis Regresi Linear Berganda}

Penggunaan alat statistik analisis regresi linear berganda yang bertujuan untuk mengetahui besar pengaruh variabel independen (bebas) terhadap variabel dependen (terikat). Analisis regresi linear berganda menggunakan alat berupa program Statistical Package for Social Science 23.0 for windows (SPSS) menghasilkan persamaan regresi linear berganda, koefiesien korelasi (R), dan koefien determinasi $\left(\mathrm{R}^{2}\right)$.

$$
\begin{gathered}
Y=8,939+0,265 X_{1}+0,28 X_{2}+0,935 X_{3} \\
+0,294 X_{4}+1,194 X_{5}-0,247 X_{6} \\
-0,215 X_{7}+1,472 X_{8}+e
\end{gathered}
$$

Keterangan:

$\mathrm{X}_{1}=$ Produk

$\mathrm{X}_{2}=$ Harga

$\mathrm{X}_{3}=$ Distribusi

$\mathrm{X}_{4}=$ Promosi

$\mathrm{X}_{5}=$ Budaya

$\mathrm{X}_{6}=$ Sosial

$\mathrm{X}_{7}=$ Pribadi

$\mathrm{X}_{8}=$ Psikologis

$e=$ Standart error

$\mathrm{Y}=$ Keputusan Pembelian.
Koefisien korelasi ditujukan untuk mengukur tingkat keeratan hubungan antar variabel independen (bebas) dengan variabel dependen (terikat). Nilai koefisien korelasi yang berasal dari perhitungan persamaan regresi sebesar 0,749 , maka dapat dinyatakan bahwa terdapat hubungan positif antara variabel produk, harga, distribusi, promosi, budaya, sosial, pribadi, dan psikologis yang berkesinambungan dalam kategori kuat terhadap variabel keputusan pembelian. Koefisien determinasi $\left(\mathrm{R}^{2}\right)$ adalah alat yang digunakan untuk mengukur kemampuan model regresi dalam menjelaskan variasi variabel dependen (terikat). Nilai koefisien determinasi atau nilai Adjusted $R^{2}$ square sebesar 0,528 . Sesuai dengan nilai koefisien determinasi, dapat diketahui bahwa variabel produk, harga, distribusi, promosi, budaya, sosial, pribadi, dan psikologis dapat menjelaskan variasi pada variabel keputusan pembelian konsumen sebesar 52,8\% dan $47,2 \%$ variasi pada variabel keputusan pembelian konsumen dapat dijelaskan dengan variabel independen yang tidak digunakan di dalam penelitian ini.

\section{Pengujian Hipotesis}

Pengujian hipotesis bertujuan untuk mengetahui ada atau tidak pengaruh variabel produk, harga, distribusi, promosi, budaya, sosial, pribadi, dan psikologis terhadap keputusan pembelian yoghurt di DKI Jakarta baik secara parsial dengan uji $t$ atau secara simultan dengan uji F. Uji F digunakan untuk mengetahui pengaruh secara simultan (bersama-sama) antara variabel independen (bebas) terhadap variabel dependen (terikat) (Tabel

\begin{tabular}{|c|c|c|c|c|c|c|}
\hline \multicolumn{2}{|r|}{ Model } & Sum of Squares & $\mathrm{df}$ & Mean Square & $\mathrm{F}$ & Sig. \\
\hline 1 & Regression & 1444,205 & 8 & 180,526 & $\begin{array}{l}16,50 \\
2\end{array}$ & $.000^{\mathrm{b}}$ \\
\hline & Residual & 1126,787 & 103 & 10,940 & & \\
\hline & Total & 2570,991 & 111 & & & \\
\hline
\end{tabular}
$4)$.

Tabel 4. Hasil Uji F

Berdasarkan hasil uji $\mathrm{F}$ didapatkan bahwa nilai Fhitung sebesar 16,502 dan memiliki nilai probabilitas 0,00 . Berdasarkan nilai $F_{\text {hitung }}>F_{\text {tabel }}$ dengan nilai 16,502 > 2,04 dan nilai probabilitas yang lebih kecil dari 0,05 (sig < 0,05), maka hipotesis $\mathrm{H}_{0}$ ditolak dan $\mathrm{H}_{1}$ diterima yang memiliki makna variabel produk, harga, distribusi, promosi, budaya, sosial, pribadi, dan psikologis atau variabel bauran pemasaran dan perilaku konsumen secara bersamasama berpengaruh signifikan terhadap keputusan pembelian yoghurt oleh konsumen di wilayah DKI Jakarta. Hasil penelitian didukung dengan penelitian 
terdahulu oleh Sesunan dkk. (2015) bahwa variabel bauran pemasaran dan perilaku konsumen berpengaruh nyata atau memiliki pengaruh signifikan terhadap pengambilan keputusan konsumen cappuccino cincau di Universitas Lampung.

Uji t digunakan untuk menunjukkan besar pengaruh satu variabel bebas secara individual dalam menjelaskan variabel terikat. Berdasarkan interpretasi nilai $t$ hitung dan nilai signifikasi setiap variabel, maka dapat disimpulkan variabel yang memiliki pengaruh positif secara parsial dan signifikan terhadap keputusan pembelian yoghurt di DKI Jakarta adalah variabel distribusi, variabel budaya, dan variabel psikologis (ditulis tebal pada Tabel 5). Hal tersebut dikarenakan seseorang memutuskan untuk melakukan pembelian suatu produk didasari terlebih dahulu pada kesadaran kebutuhan diri sendiri dan kesadaran berasal dari faktor internal seperti faktor psikologis seseorang yang menyadari kebutuhan pada suatu produk sesuai dengan Fredereca dan Chairy (2010) bahwa dinamika internal individu penting dan memengaruhi pengambilan keputusan konsumen yang tercakup didalamnya proses persepsi dan interpretasi informasi terhadap suatu produk yang didukung dengan nilai budaya dan sikap yang terbentuk.

Tabel 5. Hasil Uji t

\begin{tabular}{lcc}
\hline Variabel Bebas & $\mathrm{t}$ & Sig. \\
\hline Produk & 1,430 &, 156 \\
\hline Harga & 1,204 &, 232 \\
\hline Distribusi & 2,438 &, 016 \\
\hline Promosi & 1,500 &, 137 \\
\hline Budaya & 3,594 &, 001 \\
\hline Sosial & $-1,040$ &, 301 \\
\hline Pribadi &,- 960 &, 339 \\
\hline Psikologi & 3,530 &, 001 \\
\hline
\end{tabular}

Psikologis seseorang dipengaruhi rangsangan terhadap perbedaan keadaan yang diinginkan dengan keadaan aktual yang menimbulkan kebutuhan yang perlu dipenuhi oleh konsumen. Selain faktor psikologis, faktor budaya signifikan mempengaruhi keputusan pembelian dikarenakan budaya merupakan sesuatu yang sudah dipercayai dapat memuaskan kebutuhan pribadi pada penggunaan suatu produk. Oleh karena itu, keberadaan produk diperlukan untuk dirancang secara teliti sehingga produk dapat diterima konsumen karena nilai budaya memiliki kendali seolah menata, mengendalikan dan membuat pola pada perilaku konsumen dalam pembelian produk (Subianto, 2007). Faktor eksternal konsumen yang dikendalikan oleh produsen produk, faktor distribusi, memiliki nilai yang signifikan memengaruhi keputusan pembelian produk dikarenakan konsumen menggunakan suatu produk yang mudah ditemukan sehingga kebutuhannya segera terpenuhi dengan mudah dan saat semakin luas jalur distribusi, maka semakin besar peluang konsumen menemukan produk kemudian membelinya (Heryanto, 2015). Ketiga faktor yang memiliki pengaruh signifikan juga memengaruhi secara berkesinambungan atau saling memengaruhi, yaitu pengaruh secara eksternal konsumen (faktor distribusi) dan faktor internal konsumen (faktor psikologis dan faktor budaya). Tergantung karakteristik kajiannya, faktor budaya dan faktor psikologis dapat tidak memiliki pengaruh signifikan terhadap keputusan pembelian misalnya karena pergeseran budaya tidak menjadi alasan utama dalam keputusan pembelian dan kebutuhan yang disebabkan tekanan psikologis tidak dipahami atau tidak disadari oleh konsumen (Santoso, 2013; Manurung \& Sahla, 2020).

\section{SIMPULAN DAN SARAN}

\section{Simpulan}

Berdasarkan hasil penelitian, konsumen yoghurt di DKI Jakarta didominasi oleh Mahasiswa dengan tingkat pendidikan Strata 1, pendapatan < Rp.2.000.000, kuantitas konsumsi yoghurt per minggu $<100 \mathrm{ml}$, anggaran dana pembelian yoghurt per bulan < Rp.50.000, tempat pembelian di swalayan, dan mendapatkan informasi mengenai yoghurt ketika melakukan kegiatan berbelanja produk lainnya. Faktor perilaku konsumen lebih memengaruhi keputusan pembelian produk yoghurt di DKI Jakarta dibandingkan faktor bauran pemasaran. Faktor yang memiliki pengaruh besar dan signifikan terhadap keputusan pembelian yoghurt di DKI Jakarta terdiri dari dua variabel perilaku konsumen dan satu variabel bauran pemasaran yaitu faktor budaya, psikologi, dan distribusi sehingga dapat disimpulkan bahwa pembelian produk yoghurt di DKI Jakarta mengutamakan faktor yang berasal dari diri sendiri yang sesuai dengan kebutuhan dan kepuasan pribadi konsumen dibandingkan dengan keunggulan yang dimiliki produknya. Terdapat juga faktor dengan 
pengaruh kecil dan tidak signifikan berpengaruh terhadap keputusan pembelian yoghurt di DKI Jakarta, yaitu faktor promosi, produk, dan harga yang dapat turut diperhitungkan dalam faktor yang mempengaruhi keputusan pembelian yoghurt di DKI Jakarta walaupun pengaruhnya kecil. Selain itu, terdapat faktor dengan pengaruh negatif dan tidak signifikan berpengaruh terhadap keputusan pembelian yoghurt di DKI Jakarta, yaitu faktor sosial dan pribadi. Faktor tahapan keputusan pembelian turut memiliki pengaruh dalam proses pengambilan keputusan pembelian yang dapat dimaksimalkan untuk peningkatan penjualan produk yoghurt di DKI Jakarta.

\section{Saran}

Guna peningkatan penjualan produk yoghurt di DKI Jakarta, maka penggunaan media sosial sebagai salah satu alat untuk memperkenalkan produk yoghurt kepada konsumen yang lebih luas sehingga penjualan meningkat.

\section{DAFTAR PUSTAKA}

Asni, TU. 2018. Pengaruh Tingkat Terpaan Iklan Televisi dan Tingkat Pengetahuan Produk terhadap Minat Beli Konsumen. [Skripsi]. Universitas Muhammadiyah Yogyakarta. Yogyakarta.

[BPS] DKI Jakarta. 2020. Jumlah Penduduk Provinsi DKI Jakarta Menurut Kelompok Umur dan Jenis Kelamin 2018-2020. Tersedia online pada

https://jakarta.bps.go.id/indicator/12/111/1/ju mlah-penduduk-provinsi-dki-jakartamenurut-kelompok-umur-dan-jeniskelamin.html. Diakses Januari 2021.

Fredereca, BG, dan Chairy. 2010. Pengaruh psikologi konsumen terhadap keputusan pembelian kembali smartphone Blackberry. Jurnal Manajemen Teori dan Terapan. 3(2): 128-143.

Gayatri, IAEM. 2015. Hubungan keselamatan dan keseharan kerja (K3) dengan kinerja karyawan pada PT. UOB Indonesia Cabang Bengkulu. Jurnal Ilmiah Ekonomi dan Bisnis. 3(2): 185-186.

Heryanto, I. 2015. Analisis pengaruh produk, harga, distribusi, dan promosi terhadap keputusan pembelian serta implikasinya pada kepuasan pelanggan. Jurnal Ekonomi, Bisnis \& Entrepreneurship. 9(2): 80-101.

Kasmir, J. 2016. Studi Kelayakan Bisnis. Kencana
Prenada Media Group. Jakarta.

Kotler, P. 2005. Manajemen Pemasaran. Edisi Milenium. Jilid 3. Penerbit Indeks. Jakarta.

Logen, Y. 2015. Faktor yang Berhubungan dengan Pemanfaatan Pelayanan Kesehatan oleh Pemulung di TPA Tamangapa. [Skipsi]. Universitas Hasanuddin. Makasar.

Manurung, HP, dan H Sahla. 2020. Pengaruh faktor budaya dan psikologi terhadap keputusan pembelian sabun cream merek Ekonomi di Kabupaten Asahan. Jurnal Ekonomi Manajemen. 6(2): 102-107.

Priambodo, LH, dan M Najib. 2014. Analisis kesediaan membayar (willingness to pay) sayuran organik dan faktor-faktor yang mempengaruhinya. Jurnal Manajemen dan Organisasi. 5(1): 1-14.

Puspita, SD, Taslim, dan A Fitriani. 2015. Pengaruh harga, kualitas produk, dan citra merek terhadap keputusan pembelian yoghurt. Students e-Journal. 4(1): 1-10.

Riduwan, dan Akdon. 2020. Rumus dan Data dalam Aplikasi Statistika. Cetakan ke-7. Alfabeta. Bandung.

Santoso, DTT, dan E Purwanti. 2013. Pengaruh faktor budaya, faktor sosial, faktor pribadi, dan faktor psikologis terhadap keputusan pembelian konsumen dalam memilih produk operator seluler Indosat-M3 di Kecamatan Pringapus Kab. Semarang. Among Makarti. 6(12): 112-129.

Sesunan, TM, Y Indriani, dan I Listiana. 2015. Bauran pemasaran dan perilaku konsumen dalam pengambilan keputusan pembelian cappuccino cincau. Jurnal Ilmu-Ilmu Agribisnis. 3(1): 93-99.

Setiaputri, KA, and Y Firdaus. 2020. Meski Sehat, Makan Yogurt Berlebihan juga Dapat Timbulkan Dampak Buruk. Tersedia online pada https://hellosehat.com/nutrisi/faktagizi/efek-terlalu-banyak-makan-yoghurt/. Diakses Januari 2021.

Subianto, T. 2007. Studi tentang perilaku konsumen beserta implikasinya terhadap keputusan pembelian. Jurnal Ekonomi Modernisasi. 3(3): 165-182.

Sugiyono. 2016. Metode Penelitian Kuantitatif, Kualitatif, dan R\&D. PT. Alfabet. Bandung.

Sumarwan, U. 2011. Perilaku Konsumen: Teori dan Penerapannya dalam Pemasaran. PT. Ghalia Indonesia. Bogor.

Suprayitno, A, S Rochaeni, dan R Purnomowati. 
2015. Pengaruh faktor budaya, sosial, pribadi, dan psikologi konsumen terhadap keputusan pembelian pada restoran gado-gado Boplo. Jurnal Agribisnis. 9(2): 177-214.

Wibisono, D. 2003. Riset Bisnis: Panduan bagi Praktisi dan Akademisi. PT. Gramedia Pustaka Utama. Jakarta.

Widowati, S, dan Misgiyarta. 2003. Efektifitas bakteri asam laktat (BAL) dalam pembuatan produk fermentasi berbasis protein/susu nabati. Prosiding Seminar Hasil Penelitian Rintisan dan Bioteknologi Tanaman. Balai Penelitian Bioteknologi dan Sumberdaya
Genetik Pertanian. Bogor.

Winarno, FG. 1992. Kimia Pangan dan Gizi. Gramedia. Jakarta.

Yedida, TC, Saryadi, dan W Hidayat. 2016. Pengaruh harga, keragaman barang, dan kualitas pelayanan terhadap keputusan pembelian (Studi pada konsumen swalayan Aneka Jaya Ngaliyan Semarang). Jurnal Ilmu Administrasi Bisnis. 5(4): 449-457.

Yulia. 2015. Makanan Fungsional. Tersedia online pada

https://foodtech.binus.ac.id/2015/01/13/maka nan-fungsional/. Diakses Januari 2021. 